\title{
Competency In Critical Care Nursing With Approach Methods Journal Sharing of Critical Care (JSCC) In Nursing Profession Students
}

\author{
Heru Suwardianto*, Vitaria Wahyu Astuti \\ Baptist Hospital Health Collage, Kediri, Indonesia \\ * herusuwardianto@gmail.com
}

\begin{abstract}
Achievement of critical nursing competencies must be achieved in a variety of challenging conditions by students of nursing so that they are ready to enter the real world. The innovation of learning methods is a challenge for teachers to improve the quality of student competencies. The purpose of this research was to analyze competency in critical care nursing with approach methods Journal Sharing of Critical Care (JSCC) in nursing profession students.

The design was a pre-experimental pretest design. The population was all professional students in 2020 at Baptist Hospital Health Collage. The sample was professional students in 2020 using total sampling. The size of the study sample was 39 respondents with the inclusion of students who had completed the medical surgical nursing profession and followed the critical nursing profession to completion. The independent variable was the method of learning journal sharing of critical care (JSCC). The dependent variables were Primary Assessment, Professionalism, Competence of Nursing Care, Clinical Reasoning Process, Patient Safety, and Critical Care Exam Score. Data were collected using a questionnaire and analyzed using the Pearson test. The results showed that most respondents had good critical nursing competency scores including primary assessment: airway assessment (53.8\%); breathing assessment (56.4\%); Circulation assessment (61.5\%); Disability assessment (56.4\%); and Exposure assessment $(59 \%)$, professionalism $(56.4 \%)$, critical nursing care competencies $(79.5 \%)$, Clinical reasoning process $(71.8 \%)$, Patient safety $(61.5 \%)$ and critical care exam score $(46.2 \%)$. The result of statistical test with Pearson test obtained that the primary assessment: airway assessment $(\rho=0.038)$; circulation assessment $(\rho=0.029)$; Exposure assessment $(\rho=0.023)$, competence of critical nursing care $(\rho=0.049)$, clinical reasoning process $(\rho=0.028)$ and patient safety $(\rho=0.001)$ have a significant relationship to the critical care exam score.
\end{abstract}

Keywords : Journal Sharing, Critical Care, Nursing Profession Students 


\section{STRADA Jurnal Ilmiah Kesehatan}

DOI: $10.30994 /$ sjik.v9i2.361

ISSN: 2252-3847 (print); 2614-350X (online)

Vol.9 No.2 November 2020 Page.686-693

\section{BACKGROUND}

Critical nursing competence is one of the achievements in the nursing profession students in Indonesia. Achievement of competencies is carried out through various learning methods so that they can see the expected competency results. Nursing competence through the process of concept analysis to results. Various competency elements are assessed to see the results of the learning process. Nursing competencies apply skills in all domains in practical roles for students. Competencies are built that focus on specific outcomes or competencies, and also the need for supporting facilities to increase the level of competence, student accountability, practice-based learning, selfassessment, and individual learning experiences (Donna \& Tilley, 2008). The impact of the learning process on nursing students is a significant difference in the construct of cultural competence (Kohlbry, 2016). The potential value of nursing competency standards is needed to develop and test strong standards that can communicate the skills and knowledge needed by nurses in each health care setting (Halcomb \& Steohens, 2016). The learning environment at the hospital or on campus can improve and guarantee competence by involving learners in assessment and accountability, providing learning opportunities to students on a practical basis, and individualizing student learning experiences in the practice area. Achievement of competency in students of the critical nursing profession needs to be continually developed and continues to be given input related to obstacles and challenges.

Nurses in Indonesia in 2019 reached 345,508 Nurses, Java has the highest number of nurses. The distribution of nurses in East Java Province was 48,164 nurses. Central Java Province amounted to 45,107. West Java Province numbered 35,747 nurses, and in Jakarta, there were 26,950 nurses. The distribution of nurses at least in West Sulawesi Island was 1550 nurses, North Kalimantan was 1,587 nurses, and North Maluku was 2,062 nurses. Based on the Data of the Health Human Resources Development and Empowerment Agency of the Ministry of the Republic of Indonesia in 2017 it was found that in 2016 the total Health human resources utilized in health care facilities out of 15,2563 Health service units throughout Indonesia reached 1,000,780 people. There were 601,228 of whom were 6 medical, paramedic, and pharmaceutical health personnel. Nurses are the largest health workers who reach $49 \%$ of all existing health workers (296,876 nurses). Data BPPSDMK (Agency for Development and Empowerment of Human Resources for Health) in December 2016 total nurses in East Java reached 33,377 nurses (Ministry of Health, 2017). Other data shows that the ratio of nurses to one hundred thousand of Indonesia's population was obtained in 2014 which was 94.07 nurses per 100,000 population and estimated in 2015-2019 to be 180 nurses per 100,000 population (Kemenkes, 2017). The Nurse classification that has completed the professional level is around $10.84 \%$ in 2017. Nursing competence is evidenced by the registration sign from the Indonesian Health Workers' Assembly and in 2016 219,654 nurses have a registration certificate with the proportion of issuance of the registration letter of $41.8 \%$ (Kemenkes, 2017).

Critical nursing competency in professional students is one of the broad demands in achieving it and requires high health teamwork has led to many learning methods initiatives in education and achievement of competence. Critical nursing competencies in professional students aim to build team competencies. Most of the efforts have been made and focused on conventional methods and usually rarely use interprofessional team methods, let alone using journals or research results as material in critical nursing care by professional students. Application of research results such as journals needs to be tried in learning in nursing profession students because in them there is the latest information in 


\section{STRADA Jurnal Ilmiah Kesehatan}

DOI: $10.30994 /$ sjik.v9i2.361

ISSN: 2252-3847 (print); 2614-350X (online)

Vol.9 No.2 November 2020 Page.686-693

nursing care. If students are not exposed to journals or research results in nursing care it will be very difficult for the nursing profession to be better at sharing knowledge with colleagues or critical nursing teams (Barton \& Bruce, 2018). Management of critically ill patients is a challenge in achieving competence by nursing students. The high prevalence of comorbidity causes a significant number of critical patients in the hospital (Kaldan et al., 2019). Curricula in the nursing profession are adaptable and can be used in intensive care units and can be continuously refined with the research approach (Kopf et al., 2018).

Nursing student competencies include all the core abilities needed to fulfill the student's role of being a nurse (Fukada, 2018). It is very important the explanation of defining nursing competencies to build a foundation for the nursing education curriculum in Indonesia in preparing and providing specific learning strategies by applying research results in them such as the use of journals. The concept of fulfilling nursing competency methods is important to improve the quality of nursing, one of them is the Journal Sharing Critical Care (JSCC). The challenge remains in establishing existing competencies or that the definition and structure for nursing competencies for students. JSCC provides student experience in analyzing journals and subsequently is used in conducting nursing care to patients. The level of competency required for nursing professionals varies greatly and current knowledge related to nursing care is required by students.

\section{METHODS}

This study uses a Pre Experiment research design (Pretest design). The preexperimental research with the pretest design approach was research that focuses on the results after the intervention of the respondents and gets an actual picture from the results of quantitative data. The purpose of this study was to determine the critical nursing competencies with the method of journal sharing of critical care (JSCC) in nursing professional students. The research population was all nursing professions, students, at Baptist Hospital Health Collage in Kediri. The research sample was nurses' professional students at Baptist Hospital Health Collage in Kediri using the Total Sampling Technique. Total Sampling is a sampling technique that uses the entire population as research respondents. The independent variable of research was the method of learning Journal Sharing of Critical Care (JSCC). The dependent variables of this study ware Primary Assessment, Professionalism, Nursing Care Competence, Clinical Reasoning Process, Patient Safety, and Critical Care Exam Score. The flow of the research are 1) the students do an explanation related to the method of journal sharing of Critical Care (JSCC), 2) Students are given a format of work assignments to analyze journals or research results that focus on critical nursing care, 3) Students create integrated nursing care with intervention or measurement tools based on journals or research results that have been carried out the prior analysis. 3) The researcher measures the results of the Primary Assessment, Professionalism, Nursing Care Competence, Clinical Reasoning Process, Patient Safety, and Critical Care Exam Score. This research was conducted from March to April 2020. Data collection using questionnaires based on Eddlink Application and Google Form. The results of the study were tabulated and coded then an analysis of the frequency distribution of data and the Pearson test with $\alpha<0.05$

\section{RESULT}

The results of the study compacted 39 respondents with the composition of the sex there are 7 respondents (17.9\%) and the female sex as many as 32 respondents $(82.1 \%)$, the age of most respondents aged 27 years $(69.2 \%)$, with specialization critical nursing 


\section{STRADA Jurnal Ilmiah Kesehatan}

DOI: $10.30994 /$ sjik.v9i2.361

ISSN: 2252-3847 (print); 2614-350X (online)

Vol.9 No.2 November 2020 Page.686-693

material namely the cardiovascular system as many as 22 respondents $(56.4 \%)$. The results showed that most nursing students understood the medical problems of respiratory failure and coronary heart disease more than other medical problems. Students understand the medical diagnosis is interpreted that students understand the etiology of medical problems, clinical manifestations, pathophysiology, clinical diagnostics, medical management, assessment of nursing care, determine the diagnosis of problems based on primary assessment, arrange interventions and develop based on the results of research or evidence, and conduct evaluations.

The results showed that the evaluation of critical civil competency in the primary assessment showed that most students got good assessments. Research shows that more than fifty percent of students get good grades. Evaluation of student professionalism is obtained with the best grades. Competencies The majority of critical nursing care students get good grades. The majority of Clinical Reasoning abilities among students are found to get good grades. The ability in terms of patient safety obtained by students at most has good grades. The results showed that the Critical Care Exam Score has a close relationship with the primary assessment scores (airway, breathing, circulation, and exposure), nursing care competence, clinical reasoning process, and patient safety.

Table 1. Understanding of the most popular Medical Diagnosis

\begin{tabular}{lcc}
\hline $\begin{array}{c}\text { The most understood } \\
\text { medical diagnosis }\end{array}$ & Frequency & Percent \\
\hline PJK Coronary heart disease & 8 & 20.5 \\
\hline Respiration failure & 21 & 53.8 \\
\hline Diabetic kidney disease & 2 & 5.1 \\
\hline Shock cardiogenic & 2 & 5.1 \\
\hline Chronic heart disease & 1 & 2.6 \\
\hline Abdominal trauma & 1 & 2.6 \\
\hline Hemorrhagic stroke & 1 & 2.6 \\
\hline Shock hypovolemic & 2 & 5.1 \\
\hline Chest trauma & 1 & 2.6 \\
\hline \multicolumn{1}{c}{ Total } & $\mathbf{3 9}$ & $\mathbf{1 0 0 . 0}$ \\
\hline
\end{tabular}

Table 2. Evaluation of Critical Care Nursing Competencies

\begin{tabular}{|c|c|c|c|c|c|c|c|c|c|}
\hline \multirow{2}{*}{$\begin{array}{l}\text { Competency } \\
\text { Evaluation }\end{array}$} & \multicolumn{9}{|c|}{ Competency level } \\
\hline & \multicolumn{2}{|c|}{ Less } & \multicolumn{2}{|c|}{ Enough } & \multicolumn{2}{|c|}{ Good } & \multicolumn{2}{|c|}{ Very good } & \multirow[t]{2}{*}{ Pearson } \\
\hline Primary Assessment & $\sum$ & $\%$ & $\sum$ & $\%$ & $\sum$ & $\%$ & $\sum$ & $\%$ & \\
\hline 1. Airway & 2 & 5,1 & 10 & 25,6 & 21 & 53,8 & 6 & 15,6 & 0,038 \\
\hline 2. Breathing & 2 & 5,1 & 9 & 23,1 & 22 & 56,4 & 6 & 15,4 & 0,052 \\
\hline 3. Circulation & 2 & 5,1 & 8 & 20,5 & 24 & 61,5 & 5 & 12,8 & 0,029 \\
\hline 4. Disability & 2 & 5,1 & 10 & 25,6 & 22 & 56,4 & 5 & 12,8 & 0,107 \\
\hline 5. Exposure & 3 & 7,7 & 8 & 23,1 & 23 & 59 & 5 & 12,8 & 0,023 \\
\hline Professionality & 1 & 2,6 & 7 & 17,9 & 22 & 56,4 & 9 & 23,1 & 0,186 \\
\hline $\begin{array}{l}\text { Critical nursing } \\
\text { competencies }\end{array}$ & 1 & 2,6 & 6 & 15,4 & 31 & 79,5 & 1 & 2,6 & 0,049 \\
\hline $\begin{array}{ll}\text { Clinical Reasoning } \\
\text { Process }\end{array}$ & 2 & 5,1 & 5 & 12,8 & 28 & 71,8 & 4 & 10,3 & 0,028 \\
\hline
\end{tabular}




\section{STRADA Jurnal Ilmiah Kesehatan}

DOI: $10.30994 /$ sjik.v9i2.361

ISSN: 2252-3847 (print); 2614-350X (online)

Vol.9 No.2 November 2020 Page.686-693

\begin{tabular}{llllllllll}
\hline Patient Safety & 1 & 2,6 & 4 & 10,3 & 24 & 61,5 & 10 & 25,6 & 0,001 \\
\hline $\begin{array}{l}\text { Critical care exam } \\
\text { score }\end{array}$ & 10 & 25,6 & 2 & 5,1 & 18 & 46,2 & 9 & 23,1 & \\
\hline
\end{tabular}

\section{DISCUSSION}

Based on the results of the study showed that most students have a critical nursing interest in the cardiovascular system. Most nursing students understand the medical problems of respiratory failure and coronary heart disease than other medical problems. This shows that students are more interested in cardiovascular cases that are likely to occur quite a lot in critical nursing at the ICU. Cases of patients with respiratory failure are also very numerous and require specific nursing care and challenge students to carry out nursing care compared with interventions or tools based on research journals or based on evidence such as sleep hygiene, VAP, etc (Suwardianto, 2018; Suwardianto \& Sari, 2020, 2019). Implementation of JSCC students are asked to study cases that often occur and become a student's interest, in this case, is a patient with respiratory failure or a patient with cardiovascular disorders. The results of the study also students can do a journal analysis using PICO (population, intervention, comparison, and outcome). The results of the learning process with the JSCC approach many students use Evidence-based practice such as the bundle of Ventilator mechanic, the Bundle of VAP (ventilation associate pneumonia). The provision of high-quality critical care education has many aspects and complex problems. Health education and education providers must prepare the best practice structures and processes for training critical care specialists who meet the needs of the organization (Gullick et al., 2019).

The results showed that students were able to understand medical diagnoses to look for linkages in nursing care. Undergraduate educators demonstrate the conceptual focus of simple knowledge towards the change in clinical behavior in students to equip them to be ready to practice in hospitals (Smith et al., 2019). This understanding will facilitate students in finding journals or research results that can be applied and compared to nursing care. Students undertake PICO Analysis of journals whether they are by nursing care and nursing care plans written. Students can explain cases according to the patient's condition. Students can find the main problem based on the primary assessment in the case. The meaning is that students understand the etiology of medical problems, clinical manifestations, pathophysiology, clinical diagnostics, medical management, assessment of nursing care, determine the diagnosis of problems based on primary assessment, arrange interventions and develop based on the results of research or evidence, and conduct evaluations. Understanding critical nursing is important for students to prepare themselves to face real practice in hospitals (Suwardianto, 2013, 2016; Suwardianto et al., 2017, 2018; Suwardianto \& Richard, 2017; Suwardianto \& Selvia, 2015). Prepare yourself with a variety of learning methods one of them with JSCC is very good to try.

Based on the results of the study showed that the evaluation of critical nursing competence in professional students obtained the majority get a good assessment on several aspects including the assessment aspects of understanding primary assessment, professionalism, competence of critical nursing care, Clinical Reasoning, patient safety, and Critical Care Exam Score. The JSCC learning process is concluded to be effective and students can feel something new in the learning process. Students initially experience difficulties due to new challenges and have never done in a tight schedule and are analyzed quite a lot. Students gain new experience and try to do their best so that they can complete critical nursing care well (Suwardianto, 2014, 2018; Suwardianto \& Rimawati, 2018; 


\section{STRADA Jurnal Ilmiah Kesehatan}

DOI: $10.30994 /$ sjik.v9i2.361

ISSN: 2252-3847 (print); 2614-350X (online)

Vol.9 No.2 November 2020 Page.686-693

Yusiana \& Suwardianto, 2018). Many interventions or measurement tools can be used for critical nursing care that is beneficial for patients.

Critical nurse competencies prepared through learning methods will create nurses' experience caring for patients with intensive care. The discovery of problems and the process of finding solutions to students through journals or research results is very beneficial and students get the best solutions in working on critical nursing care. Students will be able to pass the nursing care reporting process through sharing journals of critical care (JSCC) that have been done previously. It is very finding a way to help through the process of their professional education. Students will gain meaningful experience ranging from knowing complaints to patient safety, this is following the results of previous studies which state that there is in the experience of understanding nurses will find problems of fatigue, mental status, patient safety (Sánchez Expósito et al., 2018). This research is in accordance with the results of the study which states that the use of simulation scenarios and the use of evidence are in line with the benefits and are useful for students to assess, plan, intervene and evaluate in emergencies in nursing care(D'Souza et al., 2020). Students are expected to collaborate with professionals in improving patient care in the intensive care unit (ICU) later. The competency framework for students will continue to improve their quality of interprofessional competencies. This is an effort used to support the development of attitudes, knowledge, skills, and behaviors needed for an interprofessional approach to care. Nursing students in the application of journals need to be continuously improved to support quality

\section{CONCLUSIONS}

This study supports the innovation of learning methods in students of the critical nursing profession by using EBNP through sharing journals, and a positive score is obtained in achieving student competence

\section{ACKNOWLEDGMENTS}

We thank the Ministry of Science, Research, Technology, and Higher Education of Indonesia (RISTEKDIKTI RI) for Research Grants 2019 and providing 2020. We thank you to Director of Kediri Baptist Hospital and all research respondents.

\section{REFERENCES}

Barton, G., \& Bruce, A. (2018). Teaching nurses teamwork: Integrative review of competency-based team training in nursing education. Nurse Education in Practice, 32, 129-137.

D’Souza, M. S., Labrague, L. J., Karkada, S. N., Parahoo, K., \& Venkatesaperumal, R. (2020). Testing a diabetes keotacidosis simulation in critical care nursing: A randomized control trial. Clinical Epidemiology and Global Health. https://doi.org/https://doi.org/10.1016/j.cegh.2020.03.011

Donna, \& Tilley, S. (2008). Competency in Nursing: A Concept Analysis. The Journal of Continuing Education in Nursing, 39(2), 58-64. https://doi.org/https://doi.org/10.3928/00220124-20080201-12

Gullick, J., Lin, F., Massey, D., Wilson, L., Greenwood, M., Skylas, K., Woodard, M., Tembo, A. C., Mitchell, M., \& Gill, F. J. (2019). Structures, processes and outcomes of specialist critical care nurse education: An integrative review. Australian Critical Care, 32(4), 331-345. https://doi.org/https://doi.org/10.1016/j.aucc.2018.09.007

Halcomb, E., \& Steohens, M. (2016). Nursing competency standards in primary health 


\section{STRADA Jurnal Ilmiah Kesehatan}

DOI: $10.30994 /$ sjik.v9i2.361

ISSN: 2252-3847 (print); 2614-350X (online)

Vol.9 No.2 November 2020 Page.686-693

care: an integrative review. Journal of Clinical Nursing, 25, 9-10.

https://doi.org/https://doi.org/10.1111/jocn.13224

Kaldan, G., Nordentoft, S., Herling, S. F., Larsen, A., Thomsen, T., \& Egerod, I. (2019).

Evidence characterising skills, competencies and policies in advanced practice critical care nursing in Europe: a scoping review protocol. BMJ Open, 9(9), e031504. https://doi.org/10.1136/bmjopen-2019-031504

Kemenkes. (2017). Pusat Data dan Informasi Kementerian Kesehatan RI: Situasi Tenaga Keperawatan.

Kohlbry, P. W. (2016). The Impact of International Service-Learning on Nursing Students' Cultural Competency. Journal of Nursing Scholarship, 48(3). https://doi.org/https://doi.org/10.1111/jnu.12209

Kopf, R. S., Watts, P. I., Meyer, E. S., \& Moss, J. A. (2018). A Competency-Based Curriculum for Critical Care Nurse Practitioners' Transition to Practice. American Journal of Critical Care, 27(5), 398-406. https://doi.org/10.4037/ajcc2018101

Smith, A., Carey, C., Sadler, J., Smith, H., Stephens, R., \& Frith, C. (2019). Undergraduate education in anaesthesia, intensive care, pain, and perioperative medicine: The development of a national curriculum framework. Medical Teacher, 41(3), 340-346. https://doi.org/10.1080/0142159X.2018.1472373

Suwardianto, H. (2013). Deep breathing relaxation as therapy to decrease blood preassure on hypertension patients. In Proceedings Faculty Of Nursing Of Airlangga The Fourd Internasional Nursing Conference Improving Quality Of Nursing Care Though Nursing Research and Innovations, 1(1), 1-12.

Suwardianto, H. (2014). The effectiveness of deep breathing and slow stroke back massage to decrease the blood pressure on a patient with hypertension. Indonesian Nursing Journal of Education and Clinic (INJEC), 1(1), 1-12.

Suwardianto, H. (2016). Tardive dyskenesia, motor activity, sedation scale, and cardiac workload in baptis kediri hospital. World Society of Disaster Nursing, 4(1), 1.

Suwardianto, H. (2018). Level Of Perception Emergency Skills In Youth Red Cross. JOURNAL OF NURSING PRACTICE, 2(1), 17-24.

Suwardianto, H., Prasetyo, A., \& Utami, R. S. (2018). Effects of Physical-Cognitive Therapy (PCT) on Criticaly ill Patients in Intensive Care Uni. Hiroshima Journal of Medical Sciences, 67(1), 63-69.

Suwardianto, H., Prasetyo, A., \& Utami, R. Su. (2017). Physical Function-Tardive Dyskenesia (PATD) on Critical Patients in Intensive Care Unit. Jurnal Ners, 12(2). https://doi.org/http://dx.doi.org/10.20473/jn.v12i2.4504

Suwardianto, H., \& Richard, S. D. (2017). Asuhan Keperawatan Kegawatdaruratan dan Penatalaksanaan Tindakan Kegawatdaruratan. CV Adjie Media Nusantara.

Suwardianto, H., \& Rimawati. (2018). Explicit Instruction Model (EIM): Daily Training Emergencies Preparedness (DTEP) Toward Skills of Participants the Youth Red Cross. Conferences, The 2nd Joint International, 2(2), 403-410.

Suwardianto, H., \& Sari, D. (2020). Environmental Factors of Sleep Hygiene That Influence The Level of Pain on Criticall ill Patients in Intensive Care Unit. STRADA Jurnal Ilmiah Kesehatan, 9(1 SE-Articles). https://doi.org/10.30994/sjik.v9i1.266

Suwardianto, H., \& Sari, D. A. K. W. (2019). Pain Level in Critical Patients With Sleep Hygiene Care In Intensive Care Unit. Journal Of Nursing Practice, 3(1 SE-Articles). https://doi.org/10.30994/jnp.v3i1.61

Suwardianto, H., \& Selvia, D. (2015). Buku Ajar Keperawatan Kegawatdaruratan (Perspektif, Konsep, Prinsip, dan Penatalaksanaan Kegawatdaruratan). PT. REVKA 


\section{STRADA Jurnal Ilmiah Kesehatan}

DOI: $10.30994 /$ sjik.v9i2.361

ISSN: 2252-3847 (print); 2614-350X (online)

Vol.9 No.2 November 2020 Page.686-693

PETRA MEDIA.

Yusiana, M. A., \& Suwardianto, H. (2018). The Effectiveness Of Deep Breathing And Slow Stroke Back Massage To Decrease The Blood Pressure On A Patient With Hypertension. Indonesian Nursing Journal Of Education And Clinic (INJEC), 1(1), 31-39. 